\title{
Speculum Saxonum and Ius Municpale as Sources of Law in the Works of Tucholczyk ${ }^{1}$
}

1. Tucholczyk published his works as Joannes Cervus Tucholiensis. His actual name was Jan Jelonek. In accordance with the widespread Renaissance custom, he assumed a humanistic surname, Cervus, as the Latin equivalent of Jelonek (deer). The author came from Tuchola, but no source information on his date of birth and death is available. It has been presumed that he was born in 1500 in Tuchola and died around 1557 in Kraków. He was a graduate of the University of Kraków, and did not study anywhere abroad. He obtained his bachelor's degree (baccalaureus artium) in 1523 and then the master's degree (magister artium) in 1531, but was never awarded a doctorate. Tucholczyk taught at the Cistercian school in Jędrzejów and was a lecturer at the University of Kraków. For several years, he was the head of the cathedral (capitular) school in Lvov. Although a clergyman, he remained ordained under lesser vows for a long time. During his life, he held a number of ecclesiastical offices: parish priest, canon, provost (praepositus), and episcopal official (oficialis).

As a scholar, Tucholczyk devoted himself to a variety of subjects, to which the legacy of his writings visibly attests. His published works included three theological volumes, three pieces on Latin grammar and

1 Translated from: W. Bojarski, Speculum Saxonum i Ius municipale jako źródła prawa w dziełach Tucholczyka, “Annales Universtitatis Nicoli Copernici. Prawo” 1987, no. 25, pp. 63-84 by Szymon Nowak and proofread by Stephen Dersley. The translation and proofreading were financed by the Ministry of Science and Higher Education under 848/2/P-DUN/2018. 
syntax, and two treatises on law. Tucholczyk is the first writer-lawyer who turned his attention to municipal law in Poland, and made the attempt to embark on a compilatory study of that law. Subsequent works in that field would be written by Mikołaj Jaskier, Jan Kirstein Cerasinus, Stanisław Eichler, Bartłomiej Groicki and Paweł Szczerbicz, to name only sixteenth-century authors. Some of those, such as Jan Kirstein or Bartłomiej Groicki, took ample advantage of Tucholczyk’s oeuvre, though without mentioning him by name.

The legal treaties of Tucholczyk include Farrago actionum civilium iuris Maydeburgensis and Epitome pontificii ac caesarei iuris. The first edition of Farrago was published in Kraków in 1531. It is the earliest study of municipal law in Poland and, until 1607, it saw nine further editions. The fourth edition from 1540 differs substantially from its predecessors. Already the title betokens that changes had been made, as it reads Farraginis actionum iuris civilis et provincialis Saxonici, municipalisque Maydeburgensis libri septem... It is also considerably more extensive, comprising seven books instead of three, as in the first edition of 1531, or four as in the second of 1535. First and foremost, however, it is permeated by Roman law, which the author indicated in the title (ius civile). The following five editions are essentially copies of the fourth, and this paper will rely on this version of the work.

Tucholczyk's second volume dedicated to law is Epitome pontificii ac caesarei iuris. The work was printed twice (in May and November) 1534, also in Kraków. As the title suggests, Tucholczyk is concerned with canon and Roman law. Moreover, the author also informs the reader that each chapter is supplemented with appendices containing provisions of the statutes of Polish and Saxon land law administered in the courts of the Kingdom of Poland. It is a textbook as well as a scholarly work. Tucholczyk refers to Epitome in the fourth edition of Farrago of 1540 . Both books by Tucholczyk were intended to be used by both practitioners and students. 
The legal content in these works follows a different arrangement, which is due to the fact that they are concerned with distinct matters, although certain sections from Epitome are included with hardly any modification in Farrago (1540). This is how the structure of the works is laid out:

The aforesaid edition of Farrago (1540) comprises seven books, whose translated titles are as follows: On law, justice and jurisprudence, On the acquisition of ownership, On covenants, On kinship and familial relations, On the judicial process, On the meaning of words and things, On the rules of Roman and canon law. Epitome consists of ten chapters entitled (in translation) in the following manner: On carnal kinship, On familial affinity, On legal kinship, On spiritual kinship, On marriage, On dowry law, On donations, On testaments, On succession, On legal rules.

Tucholczyk's legal works derive from the sources of Roman, canon, Polish, and German law. In this paper, we are interested in the sources of German (Saxon) law, which include Sachsenspiegel and Sächsisches Weichbild. In the 1540 edition of Farrago, Tucholczyk cites the above books of law from Mikołaj Jaskier's editions of Speculum Saxonum and lus municipale, but unlike in the previous versions of Farrago, chooses not to rely on the so-called versio Sandomiriensis.

In total, Farrago contains approximately 247 quotations from German law; 123 of those originate from Speculum Saxonum, and 20 from its gloss; Ius municipale is quoted 80 times, while its gloss is referred to 16 times.

In Epitome, Tucholczyk quotes the Saxon Mirror and the gloss according to the so-called versio vulgata, i.e. the edition on which Mikołaj Jaskier had relied, whereas The Saxon Weichbild (Liber Ottonis iuris Maydeburgensis) follows the so-called versio Sandomiriensis. German law is cited in Epitome 87 times, with 33 quotes from Speculum Saxonum and 3 from its gloss; Ius municipale is quoted 22 times and Liber Ottonis iuris Maydeburgensis 19 times. As for other German sources trans- 
lated into Latin, Tucholczyk cites distinction 2, chapter XII, part I of the so-called Magdeburgen Fragen. ${ }^{2}$ This is a ruling (Urteil) concerning testamentary freedom.

The above applies to the procedural and substantive law discussed by Tucholczyk. In this paper, I will focus on the elements of German law in the area of substantive law that the author collated and examined in Farrago and Epitome.

With respect to the division of law, Tucholczyk states that human law is divided into papal and imperial law. Papal law is established by the pope in order to govern spiritual and ecclesiastic affairs, whereas imperial law, laid down by the emperor, serves to regulate earthly and secular matters. Based on Speculum Saxonum ${ }^{3}$ and Ius municipal ${ }^{4}$, the author elucidates that God entrusted two persons in the Church with two swords that stand for two-fold-spiritual and secular-powers to rule and defend the Church: the pope holds spiritual authority-the emperor secular. The swords denote the exercise of power or courts. The secular sword is wielded to curb and punish malefactors and the wicked, while the spiritual sword serves to constrain immoral souls. If the pope is unable to improve one by bringing the spiritual sword to bear, the emperor is obligated to come to his aid with the secular sword. Still, they do so reciprocally, helping one another for the sake of defending the Christian church. ${ }^{5}$

Having discussed the compilations of Roman law, Tucholczyk-relying on Speculum Saxonum ${ }^{6}$ - observes that Saxons and Poles are not subject to Roman law, that they have their own laws as well as the municipal Magdeburg law. However, since the latter is not written down in its entirety, both Saxons and Poles may in particular cases draw upon

2 C. XII, dist. II, part. I Iuris Maydeburgensis in Alamanico. V. Die Magdeburgen Fragen, ed. J. F. Behrend, Berlin 1865, p. 124 f; Cf. K. Koranyi, Joannes Cervus Tucholiensis i jego dzieła. Z dziejów praw obcych i literatury prawniczej w Polsce, Lwów 1930, p. 18.

3 Speculum Saxonum, Book I, Article 1. Hereinafter: SS I.

4 Ius municipale, Article 7. Hereinafter: IM.

5 Farrago, Folio 3, Verso 4. Hereinafter: F.

6 SS II, 36; III, 44. 
Roman and canon law. Still relying on that custumal ${ }^{7}$, the author asserts that when confronted with absence of written law, judgements should be made in accordance with customary or similar law. ${ }^{8}$

When discussing the causes of loss of privileges ${ }^{9}$, Tucholczyk notes that privileges may be lost for numerous other reasons, and advises one to refer to the gloss to Speculum Saxonum. ${ }^{10}$

In his account of personal law, Tucholczyk refers to Saxon law only to a minor degree. Addressing the question of maturity (pubertas) and majority (perfecta discretio) in Farrago ${ }^{11}$, the author draws on Ius municipal $^{12}$, concluding that according to Saxon law and municipal Magdeburg law men become mature on reaching the age of 14, and women do so at 13 , while one comes of age-iure nostro ${ }^{13}$ —at 21.

After a detailed overview of issues relating to consanguinity (congation carnalis) in Epitome ${ }^{14}$, Tucholczyk provides Appendix 15, in which he outlines the degrees of kinship in Saxon law whilst relying on Speculum Saxonum. ${ }^{15}$ He finds that blood relations in Saxon law end at the seventh degree. It is therefore necessary that the inheritor should prove in the succession proceedings that their relationship to the decedent does not go beyond those seven degrees. ${ }^{16}$ Tucholczyk further observes that according to Saxon law husband and wife married under ecclesiastic law, as well as sons and daughters of such parents, do not establish degrees of kinship. In Saxon law, Tucholczyk emphasizes, the first degree

\footnotetext{
7 SS I in prologo.

$8 \mathrm{~F} 9$.

$9 \mathrm{~F} 10$.

10 Gloss in SS I, 9.

11 F f 287 v 288.

12 IM 26.

13 This statement indicates that Tucholczyk considers the law in IM to be Polish law or, rather, a law which applies in Polish towns (ius nostrum). A similar notion is later espoused by Jan Kirstein Cerasinus. Cf. L. Pauli, Jan Kirstein Cerasinus (1507-1561), krakowski prawnik doby Odrodzenia, Kraków 1971, p. 74.
}

14 Epitome, Folio 17 (hereinafter: E 17).

15 SS I, 3.

16 Roman law recognized the existence of kinship up to the tenth degree, See I. 3, 5, 5 (4). 
arises with the grandchildren (nepotes), the second with the great-grandchildren (pronepotes), the third with the great-great-grandchildren ( $a b$ nepotes) and so on. Kinship terminates with the seventh degree.

Having discussed the legal family ties (cognatio legalis) which are established as a result of adoption, Tucholczyk observes in Epitome ${ }^{17}$ that Saxons do not practice adoption and that succession ensues on the basis of natural kinship. ${ }^{18}$

Compared with personal law, Tucholczyk relies more extensively on the German customaries in his survey of family law. With respect to personal marital law, Cervus refers to Speculum Saxonum on two occasions. He notes that if a married woman gives birth to offspring too early before a particular time elapses, the issue may be questioned, and adds that the same happens with the children of a widow who were born too late after her husband's death. ${ }^{19}$ Tucholczyk further observes that under Saxon law the husband, having consummated the marriage, is a guardian of his wife who, given the unequal status, is subject to his law. Upon the death of the husband, the wife is liberated from the law of the husband and regains her original status, i.e. the one she had had prior to marrying. Furthermore, her guardianship is assumed by her nearest agnate as opposed to an agnate of the husband. ${ }^{20}$

Even more Saxon provisions are found in Cervus's disquisition on marital property law, in which he informs us that the husband's gift to the wife, which is known in Roman sources as ante nuptias, propter nuptias $^{21}$, dotalicium ${ }^{22}$ in canon law, and wiano [counterdowry] in Polish, is called Morgengabe or Leibzucht ${ }^{23}$ in German law.

17 E 36 Appendix XVIII.

18 SS III, 30.

19 SS I, 30; E 77 v.

20 SS I, 45; E 77 v. Tucholczyk states that under Roman law (C. 5, 4, 10; 5, 9, 2) the widow keeps the dwelling, the honour, and the dignity of the husband until she marries another.

21 C. 5, 3, 20.

22 C. 4, X, IV, 20.

23 SS I, 20; E 78; F 138-138 v. 
Tucholczyk observes that under Saxon law, a husband and wife's estate is owned indivisibly by the married couple. ${ }^{24}$ The woman receives the dowry through her oath and without witness, but the possession requires witnesses. ${ }^{25}$ As for paraphernal property in the light of Roman law, the author draws on the gloss to Speculum Saxonum ${ }^{26}$, stating that the husband should not interfere in the administration of such estate without the wife's consent, although it would seem, he notes, that the wife who entrusted her person to her husband should also surrender her belongings to his care. However, since equity demands something to the contrary, it prevails in this case. ${ }^{27}$ Based on the gloss to Speculum Saxonum ${ }^{28}$, Tucholczyk observes that husbands secure it on their property or provide guarantors to ensure the return of the dowry by the husband himself, or his father, to the wife, so that the wife does not incur loss in her dowry estate. Even without a dowry, the wife should be supported by the husband in his house for as long as she takes care of her husband. Upon her husband's death, her support should continue but outside the dwelling of the late husband if she had been badly treated there. Within a year, during which the dowry should be returned, her upkeep is to be borne by the inheritors of the husband from the proceeds of her dowry. If, the wife having consented, the husband pledged the dowry or alienated it in any other way, and after his death the wife recovers it, an action may be brought against her for deceit, in view of that fact that she had consented to it previously. ${ }^{29}$

In connection with marital property law, Tucholczyk also discusses the hergewet and the gerade. ${ }^{30}$ The wife of a military man (mulier militaris) was to leave her utensilia to her nearest female distaff relative, and the estate to the nearest man or woman of kin. The military man leaves

24 SS I, 31; E 82; F 143.

25 SS I, 20 et ibi nota; I, 24; III, 74. E 82; F 143 v.

26 Gl. SS I, 20.

27 E 82-82 v, 143 v-144.

28 GI. SS I, 45; JI, 24 gl.

29 E $82 \mathrm{v}-83$.

30 F 144-145 v. 
his war gear (arma bellica) to the nearest agnate, and the estate to the nearest relative of the same sex, provided that they are of equal birth. Other individuals who do not wear the military belt leave only their estate. Peasants who do not serve in the army do not receive the gear, otherwise known as hergewet. ${ }^{31}$ These accoutrements include a horse (dextrarius), or the best beast saddled by the husband, the sword, the shield, his best armour (pro corpore unius viri), daily attire, lectisternium bellicum, i.e. field cot, bolster, two changes of linen, bowl, basin with a towel, stove, etc. All this is called military gear (arma bellica) though other items, as Tucholczyk writes, might be added to this equipment. ${ }^{32}$ This is to go into the hands of the nearest relative of the husband on the spear side. By way of compensation, the nearest relative of the wife on the distaff side obtains the gerade. ${ }^{33}$ If the deceased male did not have an item belonging to the gear, and the wife confirmed under oath that no such thing was left upon his death, she was not obliged to provide it. ${ }^{34}$ The gerade comprises garments, cloth, fabrics the woman used, items women would wear as ornaments and which they kept hidden away under their care; furthermore, it included all gold and silver fashioned into female ornaments, all kinds of rings, bracelets and belts; also silk, cauldrons, utensils, stools, tablecloths, bedlinen, bath linen, coverlets, the bed, bowls, pillows, tables, pans, the stove and books. ${ }^{35}$ As Tucholczyk concludes, the gerade or parapherna are nothing else than domestic furnishings (supellex domestica). ${ }^{36}$

In his discussion of tutelage and curatorship in Farrago ${ }^{37}$, Tucholczyk relied chiefly on Roman law. Nonetheless, he refers once to Speculum Saxonum ${ }^{38}$, twice to Ius municipale ${ }^{39}$, and quotes the gloss to the

\footnotetext{
31 SS I, 27.

32 IM 25; SS II, 24.

33 SS I, 22-23.

34 IM 25.

35 IM 23.

36 SS I, 27.

37 F $185-187$ v.

38 SS I, 10.

39 IM 26.
} 
latter on five occasions. ${ }^{40}$ The author underlines that among the three types of guardianship (testamentary, statutory, and juridical) the testamentary type is the most important and the most privileged. Where a guardian has not been designated by testament, the judge-ex officio appoints the nearest agnate, a relative on the spear side, to be the guardian. If there is no such agnate to be appointed, the judge may compel an unrelated individual to assume guardianship. The guardian should take care of their ward until the latter reaches maturity, unless they refuse guardianship by invoking statutory impediment. ${ }^{41}$ As the guardian bears the burdens and losses associated with the administration of the ward's estate, it is just-Tucholczyk stresses - that they should have benefits as well. If the ward owns e.g. a vineyard, garden etc. and the guardian incurs expenses for their cultivation, he might derive profit (fructus) free of charge (census), unless they have obliged themselves to one. Whatever property the guardian accepted on assuming guardianship, they are obliged to return the same, for instance if a field had been sown, a similarly sown field shall be returned. ${ }^{42}$ Tucholczyk also observed that under Saxon and Magdeburg law, the guardianship terminates when a man reaches 14 and a woman 13 years of age, thus reaching maturity.

With respect to real rights, Tucholczyk again relies primarily on Roman law, but he also takes advantage of the Saxon custumals. Having presented and explained almost all divisions of property in Roman law, this is how he speaks of the division into movables and immovables: the movables are such property that can be easily relocated from one place to another, such as slaves, cattle, clothing, money, and others; immovable property cannot be easily relocated from one place to another, and of that we have to kinds: some are standing, as for instance a house, while the other recumbent, as for instance fields or meadows. ${ }^{43}$

40 IM 26 gl.; 23 gl.

41 IM 26; F 185.

42 IM 23 gl.; F 260.

43 SS I, 3; F 86. 
Speaking of ownership, the author draws on Ius municipale to state that it possession cannot be taken away from anyone, even if the owner possessed a thing in bad faith, unless they have been charged in court, defeated and lawfully banished following the judgment. ${ }^{44}$ Using the gloss to the Saxon Mirror ${ }^{45}$, the author explains that bad faith occurs when a person consciously possesses a thing belonging to another or deceitfully incites a seller to sell it, or purchases something despite prohibition, or purchases a thing from a ward without the consent of the tutor. $^{46}$

Regarding usucaption, Tucholczyk outlined it in accordance with Justinian's law. However, when addressing periods of limitation, he also provides those stipulated in Saxon law for the sake of comparison. Thus, under Saxon law, the period of limitation for usucaption of chattels is one year, whereas for immovables it is 30 years, one year and one day contra absentes, and one year and a day contra praesentes; 40 years against the Church, 5 years against the empire; against the emperor or empress effective immediately (in instanti); no acquisitive prescription operates with respect to towns. ${ }^{47}$ Usucaption of donated items ensues after three days (triduum). ${ }^{48}$

Discussing actio familiae erciscundae in the light of Speculum Saxonum, Tucholczyk observes that the division of inheritance between two beneficiaries is carried out by the elder of these, whereas the younger is entitled to choose between the portions; if the individual who has the right to effect the division does not wish to do it, the division is made by a judge. ${ }^{49}$ The author also refers to the Mirror addressing the division of leasehold estate (bona censualia). ${ }^{50}$

\footnotetext{
44 IM 29; F 88 v.

45 SS I, 29 gl.

46 F 89.

47 SS I, 28; II, 42; IM 20, 140; F 92 v.

48 SS III, 81; IM 30; F 92 v.

49 SS III, 29; F $189 \mathrm{v}$.

50 SS III, 29; F 190.
} 
As for the vindication action, Tucholczyk also devotes some attention to the possibilities of defence available to the owner, noting that in Saxon law the defence may be threefold. One may claim that they received the thing through donation, but then they are obliged to appoint the warendator (guarantor); if they claim that they have purchased the thing at a marketplace (in communi et libero foro) and cannot provide a warendator, they lose the money and pay a fine (mulcta) to the judge. They may claim that they have raised the animal or made a thing themselves, but a third party should provide proof to that effect. They may claim that they have inherited the thing, but in such a case they are expected to prove it. ${ }^{51}$

Still on the topic of the vindication claim, Cervus discusses arrestum, or pre-emptive detention, relying on the Saxon custumals. He explains that arrestum simply means preventing displacement of a person or their property until that person has responded to the plaintiff. Because arrestum is a severe measure, it must not be employed by the judge for trivial reasons. Tucholczyk recalls the principle of odia restringi, favores convenit ampliari, to assert that one should comply with the infallible rule whereby arrestum is applied first to property and only then to persons. With respect to the wealthy and the land-owners who are solvent, arrestum is not to be employed. In the case of persons who do not possess land nor meaning, such as gamblers, drunkards and wastrels whose assets do not suffice to pay the debts, such people as well as their effects can be placed under arrestum, provided that the things are detained first and the persons only after that. ${ }^{52}$ As to the manner of the detention (arrestatio seu vendicatio seu allocutio), Cervus also draws on the Saxon compilations. ${ }^{53}$

Underlining that emphyteutic contract should be concluded in writing, Tucholczyk makes references to Speculum Saxonum ${ }^{54}$ and Ius municipale. ${ }^{55}$

51 IM 136; SS II, 36; F 94-94 v.

52 IM 53; F $94 \mathrm{v}$.

53 SS II, 36; IM 132, 138; F 94 v.

54 SS III, 79; F 198 v.

55 IM 7; F 198 v. 
As is known, obligations had not been sufficiently covered in the German customaries, therefore in Farrago Tucholczyk discussed them extensively whilst relying mainly on Roman law and, with respect to some of the institutions, drew on that legislation exclusively. However, even here he took ample advantage of the information contained in Speculum Saxonum and Ius municipale, as well as their glosses.

Tucholczyk writes that there are two types of guarantors: judicial and non-judicial. Non-judicial guarantors swear oaths and guarantee out of court; they may deny having given guaranty and may be released upon oath where there is no sufficient proof. Judicial guarantors vouch for a person at court in civil and penal proceedings; those cannot be released and are obliged to pay the defendant's liability in the amount for which they have guaranteed. ${ }^{56}$

As for the effects of guaranty, Tucholczyk observes that its consequences in civil cases are graver than in penal ones. In the former, if a person has guaranteed for another and the primary debtor who is to be held liable in court fails to appear, the guarantor by default assumes the liability as the accused (accusatus) and has to pay should they lose. In contrast, in penal cases the guarantor is not under obligation to suffer punishment for the person they have guaranteed for, but has to pay wergeld, if the complaint seeks capital punishment (in vitam); when the complaint seeks corporal punishment (ad carnem et cutem), they are released for half of the wergeld, which then belongs to the plaintiff, not the judge who receives the payment of the fine. ${ }^{57}$ Tucholczyk notes that no one is obligated to appoint guarantors above the amount of their wergeld, unless the matter concerns debts which have been recognized or confirmed under law. ${ }^{58}$

Based on the gloss to the Saxon Mirror ${ }^{59}$, Tucholczyk discusses five privileges (documenta) of non-judicial guarantors. The plaintiff should

56 SS III , 9 gl.; IM 27 and 117. F 180v-181.

57 SS III, 9; IM 117; F 181.

58 SS II, 10; F 181.

59 SS III, 9 gl.; IM 31; F 181 v. 
first sue the primary debtor if they are in the country (provincia); if the latter is absent, a period of time (induciae) should be designated within which they are to appear; it is only then that the guarantor can be held liable. Satisfaction from the estate of the primary debtor that has been encumbered to the benefit of another cannot be sought (impeti et alloqui) prior to an action being brought against the guarantor. If the primary debtor promised money and is unable to raise it but possesses inherited estate, then the creditor is obligated to find a purchaser or accept the estate in accordance with the estimation of the judge. Where there are several joint guarantors (manu coniuncta), if one of them has satisfied the obligation, the others are released from it, while the former is entitled to action seeking compensation of parts (partes) from the latter. The creditor who accepted a pledge and the guarantors at the same time, cannot sue the guarantors unless such a creditor returns the pledge to them beforehand. Tucholczyk observes that under Roman law ${ }^{60}$ obligations rest not only with the guarantor but also their successors, whereas the laws of the Saxons stipulate otherwise. ${ }^{61}$

When discussing the elements of validity (perfecta, firma, valida) of sale-and-purchase in the light of Roman law ${ }^{62}$ (consensus, pretium, res) as well as proofs of agreement (arrha, mercipotus), Tucholczyk states that Saxon law $^{63}$ requires that the handover of goods (resignatio), and in particular real estate, happen before a court. As Tucholczyk explains, resignatio denotes the legal act of surrendering (traditio) property which has been sold, or else inherited from the father with the consent of successors, or without the consent if the property has been acquired with money. ${ }^{64}$ Relying on Ius municipale ${ }^{65}$, the author subsequently discusses admittance (intromissio). Intromissio should take place before lay

60 I 3, 20, 2.

61 SS I, 6 gl. F 181v-132.

62 D. 18, 1, 12-14.

63 IM 140.

64 IM 20; F 153 v.

65 IM 20. 
magistrates (quattuor scamna), i.e. in the presence of a convened bench (iudicium bannitum) with jurisdiction over the estate, so that the sale is confirmed and the handover promulgated in accordance with the law (prout iuris est). The purchaser, together with the judge and the lay magistrates go to the site to perform the intromissio. The judge enters the house, or premises of the property (area) if no house is there, the others remain outside; he takes the purchaser by the hand and, with the magistrates in attendance, ushers the purchaser in whilst saying the prescribed formula, after which all return to the court. ${ }^{66}$

Regarding the liability of the seller, Tucholczyk remarks that in Saxon law the seller is obliged to indemnify (varendare) the purchaser for a year and a day contra praesentes and for 30 years, a year and a day contra absentes. ${ }^{67}$ Meanwhile, Tucholczyk notes, according to the custom established in the Kingdom of Poland the seller of a horse must make the three following promises: that the horse is not short-winded, that it does not suffer from rheumatism, and that it is not skittish. ${ }^{68}$

When discussing a contract of lease as provided for in Roman law, Tucholczyk supplies the information that within one and a half years (anno medio sive quartali) all effects that the lessee (homo censualis vel inquilinus) has brought into the rented house automatically become a pledge (pignus) or surety (vadium) for the owner. ${ }^{69}$

In relation to loan agreements, Cervus devotes some more attention to debts in general, also drawing on the Saxon Mirror. ${ }^{70}$ For instance, he lists five ways of settling a debt: by paying the kind of money that constituted the object of the obligation; if the type of money has not been specified in the agreement, then the amount should be repaid with the currency which is in widespread circulation in the country (provincia), which is used

66 F 154.

67 SS II, 29; SS III, 4; IM 140 gl.; F 155.

68 IM 140 in marg; F 155 v. Tucholczyk provides a specimen of an in perpetuum entry for a house.

69 IM 140; F 158.

70 SS III, 40. 
there and serves to purchase bread and beer. The remaining four methods of clearing a debt are discussed on the basis of Roman law. ${ }^{71}$

Tucholczyk relies on Saxon law in his description of the action (querella) of debt. If recovery is sought in court (fit querimonia iudicialiter), a two-week period is decreed (quindena) in which the obligation is to be performed; if the debtor fails to perform it by the designated deadline, the judge imposes a fine and sets another time limit of eight days, then three, then two, and eventually one day (ad crastinum). Each successive failure to meet the obligation involves a fine imposed by the judge. Ultimately, if the debtor has not fulfilled the obligation and has not paid the fine to the judge, then their chattels are considered a pledge so as to force the debtor to fulfil the obligation to the creditor and to pay the fine to the judge. In the absence of chattels, the creditor is admitted into property (ad proprium). The judge should make an assessment of the pledge to determine whether it is equivalent to the amount of the debt. If so, the judge may sell it and settle the claim of the creditor, or give the creditor exactly as they require and the creditor, perforce, has to agree. If the pledge is below the amount of the debt, the debtor may be compelled to provide surety. If the debtor has no assets or guarantors, the judge should place them at the disposal of the creditor. If the latter is an alien (advena) they can take the debtor with them, if they are unable to support them in the town (municipium). In such a case, however, the creditor has to provide guaranty (fideiussoria) that the person will be returned without harm to body and health. Should the creditor be unable to give such guaranty, the debtor must remain in the town, in the house of the judge, who may put them in fetters (compedes), ensure the provision of work and food as for their own family, since the debtor was neither a thief nor an accomplice of thieves; they cannot call for another punishment for the debtor, given that the debtor went to prison voluntarily. ${ }^{72}$

71 F $162-162 \mathrm{v}$.

72 IM 34, 93; F 163 v. 
Tucholczyk also considers other instances of the action of debt. If a person sued for debt declares that the plaintiff has remitted their debt but fails to prove it, the plaintiff takes an oath. Similarly, when the defendant responding to the complaint (quaerimonia) of the plaintiff (querulator) declares that they have fulfilled the obligation, then they have to prove it, assisted by two others (mettertius); the latter must be conversant with the affairs and have heard and seen the fulfilment of the obligation. This procedure applies to a debt which has not been stated in writing. If the debt has been certified in writing, the debtor has to prove that the obligation has been settled by means of a document, or aided by five witnesses. For an obligation owed to a deceased person (post mortum manum), the attestation of seven witnesses is required..$^{73}$

Tucholczyk discussed yet another related case: a situation when a person sues another for debt before a judge and the debt is recognized, e.g. through the testimony of witnesses; here, the debtor has to fulfil the obligation on the same day. ${ }^{74}$ Where the action is concerned with a debt of money, one should demonstrate on what grounds the debt is due; if it has been incurred due to playing dice or entertainment (ex alea vel ludo), the debtor does not have to pay it, and nor is the judge obliged to award repayment. ${ }^{75}$

If a suit (actio) concerns due payment (merces merita), one files a plea with the court against the successors of the deceased owner or against the owner. If repayment is claimed from a successor who refuses to acknowledge it, the creditor should substantiate their claim with an oath; if the debtor defaults on payment for over a year, the creditor should prove it with an assistance of six others (metseptimus). If a payment is sought from a living owner, the creditor should support their claim with an oath (ad sacra). The owner, wishing to prove that the obligation has been ful-

73 SS I 65; SS II, 6; SS III, 85; IM 27, 68; F 164.

74 IM 46, 93; F 164.

75 IM 103; F 164 v. 
filled, has to do so through an oath with two other persons (mettertius). When an employer dismisses their hired labourer (mercenarius), they are to pay the entire consideration. If an employee insolently abandons their work, they need to pay their principal as much as they would have been paid by the principal; if a portion of their wage has already been paid, the employer must pay back twofold. ${ }^{76}$

With regards to successors' obligation to settle debts, Tucholczyk also takes advantage of the provisions of Saxon law. An inheritor, the author writes, whether man or woman, must pay back legally corroborated debts, provided that the movable estate allows it. However, debts need not be paid by a successor from their own estate or the inherited estate which has been transferred to another person, because ownership cannot be alienated without the consent of inheritors. Debts owed to the decedent should be paid to the successors. ${ }^{77}$

Concerning loans for use (commodatum), which Tucholczyk discusses chiefly on the basis of Roman law, it is noted that according to the Saxon Mirror a person who received anything as a loan for use, borrowed anything, or promised anything by way of stipulatio, is obligated to return or fulfil it; and whatever they happen to do, they should consider it valid and gratuitous (ratum et gratuitum). If they subsequently wish to deny, they may seek release by means of an oath, until the case is brought before a judge, where the plaintiff can defeat them through the testimonies of two witnesses and the judge. ${ }^{78}$

Based on Speculum Saxonum, Tucholczyk states that the item loaned can only be recovered from the commodatary. A person who lent a horse, garments or any other things for use, or pledged them, or a thing found itself in any other way-albeit upon consent-beyond their control and the recipient sold it, made it an object of another obligation, disposed of it, lost it through gambling, theft, or robbery, the commodator 
can only claim it from the commodatary, and if the former is dead, their successor may assert the claim pursuant to the law in court. ${ }^{79}$

In his discussion of pledges, Tucholczyk relies mainly on Roman law, but on several occasions refers to the Saxon compilations as well. ${ }^{80}$ As for deposits, the Saxon Mirror is cited only once, in connection with the liability of the depositary. ${ }^{81}$

In Epitome, the author elaborates very extensively on donations, availing himself almost entirely of Roman law (as he takes canon law into account as well, albeit to a minimal degree). However, the appendices provided at the end of the chapter contain Saxon regulations pertaining to donations. Those are sourced from Liber Ottonis iuris Maydeburgensis although no detailed notes were provided. Thus, with respect to donatio ante (propter) nuptias, Tucholczyk observes that under Magdeburg law women received their counterdowry for life. After the husband's death, the wife does not hold any portion of the estate, unless she has received such an endowment from the husband or was promised a dower before a convened bench (iudicium bannitum). He also adds that neither the dower nor the counterdowry are hereditary, and upon her death such estate returns to the husband's successors. If anything has been donated or waived to the benefit of a man or woman before a convened court, the donee is at liberty to do what they like with their portion of the gift. Tucholczyk writes that Saxons have their own and particular laws governing donations. If anyone wishes to make a donation from their own estate of inherited immovable property, they are prohibited from doing so without the consent of the successors and without allowing for a statutory period, as they would unlawfully alienate that which they must not alienate, and a successor would be entitled to claim recovery in court. ${ }^{82}$ Whatever a husband donates before a convened bench in the presence of a judge and lay magistrates, the recipient gives one solidus to acknowledge the

79 SS II, 60; F 168.

80 SS II, 24; III , 5; II, 60 gl.; III, 5; IM 20 gl. F J69-169 v.

81 SS III, 5. F $172 \mathrm{v}$.

$82 \mathrm{SS}$ I, 52. E $90=107 \mathrm{v}$. 
gift, which the magistrates take for themselves. ${ }^{83}$ Whatever a husband might give in a court, though he may have possessed it in peace for a year and a day, it is better to do so before the judge and lay magistrates rather than alienate it on one's own. ${ }^{84} \mathrm{~A}$ wife cannot donate, sell or relinquish estate without the consent of the husband, as it is presumed that they own it jointly. ${ }^{85}$ The wife cannot transfer her effects to another person. ${ }^{86}$ If a husband or wife receives a donation before a convened court, they may do with their gift as they please. ${ }^{87}$ If a husband possessed chattels and, together with his wife, added to the inventory thanks to work or good fortune, he may grant it for life (in valitudinem vitae) to the wife or another person. ${ }^{88} \mathrm{~A}$ husband cannot donate movable possessions (mercimonia) inherited after his father to his wife without the consent of his successors, unless he does so before a judge and lay magistrates. ${ }^{89}$ If a husband donated to the wife buildings erected on leased land (bona censualia) with the knowledge of the owners as well as the neighbours, and introduced the wife into possession, then following his heirless death a successor cannot recover them without the consent of the recipient of the gift. In turn, if a stead (fundus), i.e. buildings and the stock were the property of the husband and have been given to the wife as a gift, a successor may recover them, unless the donation has been executed in court with the consent of that successor. If a leasehold estate (bona censualia) is hereditary, a husband cannot donate them to his wife without the consent of the successors or the owner of that estate (dominus proprietatis).$^{90}$ If children attempt to take away the counterdowry from a widow, she can retain it by calling upon seven witnesses who were present as the gift was being made. If a husband did not grant his wife any portion in his estate,

83 Liber Ottonis iuris Maydeburgensis. Hereinafter as: LO.

84 LO. E 90, ap. II.

85 SS I, 45. E 90, ap. III.

86 SS I, 31. E 90, ap. IV.

87 LO. E 90 , ap. V.

88 LO. E 90, ap. VI.

89 LO. E 91, ap. VII.

90 LO. E 91, ap. VIII. 
she is to remain on its premises, and the children should provide her with all the necessities as long as she stays a widow. ${ }^{91}$ Donation can only be proved by the donee. ${ }^{92} \mathrm{~A}$ son is a guest (hospes) on the estate of his mother and vice versa. ${ }^{93}$ If a widow remains without a division of profits for a longer or shorter period of time, then when such a division is made, the widow shall receive as much as she would have obtained at the time of the death of her husband. ${ }^{94}$ If a widow continues to abide on the estate of her husband with her children, and a son is married and then dies, the son's widow takes precedence over the mother in terms of return of the dowry and homestead effects (utensilias) as well as the provisions of food (cibaria domestica), while the fact that the mother has not yet received her dowry is immaterial. If a married son dies on the estate of the mother, and the latter is able to prove peaceful possession, then she takes precedence over her daughter-in-law as to the return of the dowry. ${ }^{95}$ It is fair for women to obtain dower from the estate of their husbands with the consent of the successors in courts which hold jurisdiction over the estate, provided that a judge with royal mandate (bannus) sits there. ${ }^{96}$ Women cannot be deprived of their dower, either by natural successors or children born posthumously ${ }^{97}$ If a person has sold or donated anything and subsequently seeks to recover them, the purchaser or the donee shall lawfully keep those things if they take oath with two others (mettertius) swearing that the thing has been sold or given to them as a gift. ${ }^{98}$

Tucholczyk again draws on Saxon law when discussing delictual obligations, though only to a limited extent, as his disquisition in this respect relies chiefly on Roman law. Having cited the Roman definition

\footnotetext{
91 LO; E 91 v, ap. IX.

92 SS III, 83; E 91 v, ap. X.

93 SS I, 20; E 91 v, ap. XI.

94 SS I , 20; E 91 v, ap. XII.

95 SS I, 20; E 92, ap. XIII.

96 SS I, 21; E 92, ap. XIV.

97 SS I, 21; E 92, ap. XV.

98 SS III, 4; E 92-92 v, ap. ultima.
} 
of theft, Tucholczyk refers to Speculum Saxonum to state that a thief is an individual who takes a thing belonging to another for their own use, without consideration of the owner of that thing..$^{99}$ He further observes that according to the laws of the Saxons and municipal Magdeburg law, a thief should be hanged; if, however, they have committed theft below the value of three solidi, then they should be punished in skin and hair (in cute et crinibus). ${ }^{100}$ Punishment in skin and body (in cute et carne) consists in flogging under the pillory (ad statuam virgis caeditur) and cutting off an ear; if they have no ear, they should be branded on the face; if they have had their face branded twice already, then they should be hanged (patibulum). ${ }^{101}$ A stigma is branded on thieves who have committed theft in daylight. Thieves of purses (bursae) are branded on the face, with subsequent offence their ears are cut off, then branding iron is used to mark them with a cross on their forehead, and they are flogged each time. The marks are branded so they may be recognized and avoided. If a branded individual commits repeated theft, they should be hanged (insigniri fune vel catena in patibulo). This is because theft is more widespread than other crimes and hence should be punished more severely. Once hanged, a thief is seldom buried, in order to deter others. ${ }^{102}$

Punishment for robbery (rapina) is discussed from the standpoint of Roman law and the Saxon Mirror to some extent. Tucholczyk thus notes that according to our laws, capital punishment or mutilation (mutilatio membri) are inflicted depending on the severity of the crime. Robbers should be pursued with clamour and may be killed when committing the crime or escaping. ${ }^{103}$

Tucholczyk also relies on Speculum Saxonum when he addresses the offence of unlawful damage (damnum) to somebody else's property.

99 SS I, 61; F 190 v.

100 SS II, 13; IM 38; F 131 v.

101 IM 38 gl; F 191 v.

102 SS II, 13; F 192 v.

103 SS II, 68; F 193. 
No liability attaches to the mentally ill and children who are incapable of being guilty because they cannot sink so low as to face extreme penalty; therefore, if a boy kills or maims a person, his guardian is to pay compensation in the amount of the wergeld from the estate of their ward; this also applies to other damage that boys may cause, provided that it is proved. ${ }^{104}$

As for liability for damage caused by animals, Tucholczyk states that if a domesticated animal (e.g. pig or bull) inflicts damage, then compensation — corresponding to the wergeld or value - is paid by the owner of the animal if they keep it in their possession after the damage has arisen; however, if they have banished the animal and no longer feed nor water it, compensation need not be paid; the aggrieved party can take the animal, if they want, by way of compensation for the damage. ${ }^{105}$ If a person keeps wild animals (bears, wolves, foxes, panthers, lions, deer, monkeys) and they have caused the damage, then compensation must be paid by the owner. If they do not renounce the ownership following the damage by driving them out and refusing them feed, they are not released from the obligation to pay compensation when the aggrieved party proves, aided by two others (mettertius), that the former owned them until the day when the damage arose. ${ }^{106}$ Still on the subject of indemnification for damage inflicted by animals, Tucholczyk writes that if such damage has been caused by a dog, its owner may prove that they were unaware that the dog bites. If the dog was chained, guilt lies with the one who has been bitten. If a person has set a dog on somebody else's cattle and the animals were bitten, they are not obliged to compensate for it. If a dog bites animals on a road, the owner of the dog is to pay compensation. If a person kills a dog that is causing damage to them, they are not required to pay compensation if they swear that they have done it out of necessity. ${ }^{107}$

104 SS I, 40; II, 45; F 193 v.

105 SS II, 40, 55, 60; F 194 v.

106 IM 122; F 195.

107 IM 122; F 195. 
Cervus cites Saxon laws on three occasions when discussing liability for insults (iniuria), stating that actio iniuriarum requires seven witnesses. ${ }^{108} \mathrm{He}$ then observes that the abused party may file a penal or civil complaint in respect of any insult; in the case of a civil suit, an assessment is made and subsequently a financial penalty is imposed on the offender; in penal suits, the judge sentences the defendant to punishment in body or humiliation. ${ }^{109}$ The author also refers to the Mirror in connection with insulting one's wife and children. ${ }^{110}$

With respect to succession law, whose overview is again based chiefly on Roman legal sources, Tucholczyk does not fail to note how Saxon laws provide in that respect. He therefore states that the testaments made whilst being of legal age, sound in mind, without fraud and deceit, cannot be invalidated. ${ }^{111}$ One learns that neither husband nor wife-while incapacitated by reason of health-may spend more than three solidi out of their estate without the consent of the successors; a wife cannot do so either without the consent of her husband. ${ }^{112}$ At the end of the chapter devoted to succession law which, as already noted, relies primarily on Roman sources (and to a very limited extent on canon law), the author supplies 23 solutions relating to succession law found in the Saxon compilations, by quoting the provisions contained in Speculum Saxonum and Iiber Ottonis iuris Maydeburgensis.

The above outlines the regulations recorded chiefly in Speculum Saxonum and Ius municipale, which Jan Jelonek Cervus from Tuchola chose to cite in his two legal treaties, that is Farrago from 1540 and Epitome, published in 1534. The degree to which they were taken into consideration by the author may not be all too extensive, particularly in comparison with

108 SS I, 70; IM 91; F 196.

109 SS I, 68; IM 90; Cf. I. 4, 4, 10; F 196.

110 SS I, 68; III, 45; F 197.

111 SS I, 52. E $119 \mathrm{v} ; 121 \mathrm{v}$.

112 IM 65; F 130 v; E 113 v. Tucholczyk cites a judgement of a Magdeburg court concerning legacies made while in a sick-bed (C. 12, D. II, p. I in Almanico), and observes that the provisions of the Magdeburg law were condemned by canon law as godless and contrary to Roman law. Cf. C. 6, 22, 3. F 130. 
Justinian's codification or even canon law. Nonetheless, Tucholczyk does take advantage of Saxon law to a varying degree when discussing each branch of personal, procedural and substantive law.

\section{Literature}

Behrend J.F. ed., Die Magdeburgen Fragen, Berlin 1865.

Koranyi K., Joannes Cervus Tucholiensis i jego dzieła. Z dziejów praw obcych i literatury prawniczej w Polsce, Lwów 1930.

Pauli L., Jan Kirstein Cerasinus (1507-1561), krakowski prawnik doby Odrodzenia, Kraków 1971.

Farrago.

Iuris Maydeburgensis in Alamanico.

Ius municipal.

Speculum Saxonum. 